\title{
RELATIONSHIP OF SALIVA pH AND DMF-T INDEX IN METADON HOUSING THERAPY IN YOGYAKARTA CITY
}

\author{
Hanik Mariaa*); Diyah Fatmasari ${ }^{\mathrm{b}}$ \\ a Duren Community Health Services; \\ Jl. Mayor Soeyoto No.19, Piyato, Duren, Bandungan District, Semarang, Central Java, Indonesia \\ ${ }^{b}$ Poltekkes Kemenkes Semarang; \\ Jl. Tirto Agung, Pedalangan, Banyumanik District, Semarang City, Indonesia
}

\begin{abstract}
One of the factors causing dental caries is salivary state. Drug addicts may have different salivary pHs due to the drug content that is commonly consumed. The purpose of this study is to determine the relationship of salivary $\mathrm{pH}$ to the DMFT index in the Methadone Maintenance Therapy group in the city of Yogyakarta. This type of observational analytic study is a Case control design. The samples were 64 subjects, divided into 2 groups: case and control groups. Case groups were people who got methadone maintenance and members of the Methadone Maintenance Therapy Program at the Gedongtengen Health Center in Yogyakarta. Saliva pH measuring instrument is a $\mathrm{pH}$ strip. The relationship between salivary $\mathrm{pH}$ and DMFT was tested using the Spearman rank test. The results show that the average DMF-T in the case group was 8.4, higher than that in the control group (2.1) while the saliva $\mathrm{pH}$ of the PTRM group in the acid category (5.8) was lower than that in the control group with a neutral $\mathrm{pH}$ category (6.6). Spearman rho shows significance level of 0,05. There was a significant relationship between salivary $\mathrm{pH}$ and DMF-T index in the Methadone Maintenance Therapy group in Yogyakarta City.
\end{abstract}

Keywords : $p H$ saliva, DMF-T, Metadone therapy

\section{Introduction}

Riset Kesehatan Dasar (Riskesdas) 2018 states that mean of decay, missing, filling tooth (DMF-T) at Indonesia community is 1.6;2,9; 0.08; and 4.6. (Kementerian Kesehatan RI Badan Penelitian dan Pengembangan, 2018). Heroin addicts were 47 person $(97.92 \%)$ with caries and mean of decay, missing, filling tooth was 7.83; 3.10; 0.15; and 11.08 (Isadora Gracia, Rensa, Minawati, Teguh Sarry Hartono, 2014). Such researches showed the dental health condition of heroin users which had a therapy at methadone housing maintenance.

Dental caries is a disease of dental tissue that begins with tissue damage from the surface

\footnotetext{
*) Corresponding Author (Hanik Maria)
}

E-mail: mariahanik85@gmail.com of the pit teeth, fissures, and inter-proximal areas, and then extends towards the pulp. Every person can experience dental caries on one or more surfaces which can spread to the inside of the tooth, from enamel to dentin and to the pulp. Factors that cause dental caries include saliva, microorganisms and carbohydrates, anatomy and tooth surface (Tarigan, 2013).

The causes of caries are the bacteria Streptococcus mutans and Lactobacilli. These specific bacteria convert glucose and carbohydrates in food to become acidic through the fermentation process. Acid continues to be produced by bacteria and eventually damages the structure of the teeth little by little. Then the plaque and bacteria start working 20 minutes after eating (Ramadhan \& dkk, 2016). 
Saliva plays an important role at balancing of demineralization and remineralization process which determine the caries attack (Tarigan, 2013). If the frequency of consuming easily fermented carbohydrates increases, the plaque is in critical $\mathrm{pH}$ for a longer time to demineralize the enamel (around $\mathrm{pH}$ 5.5). Low $\mathrm{pH}$ conditions support the proliferation of acidresistant bacteria that disturb the $\mathrm{pH}$ balance so that the demineralization process occurs (Tarigan, 2013).

Saliva is a collection of various fluids in the oral cavity. The relationships between saliva and caries are that saliva is needed to clean the teeth in sufficient quantities, to prevent the emergence of plaque that is high enough and to make the atmosphere in the mouth become acidic, which causes caries. Saliva has an average $\mathrm{pH}$ between 5.25-8.5. Saliva is released by the three glands including the parotid gland, the sublingual gland, and submandibular glands for 24 hours as much as $1000-2500 \mathrm{ml}$. And it will be more acidic at night because less saliva is released.

"Methadone Maintenance Therapy is one of the opiate replacement therapies needed for opiate addicts to control their dependency behavior and also as an effort to reduce the adverse effects of HIV / AIDS transmission" (Kementerian Kesehatan RI, 2013).

Metadona is "Narcotics in the form of a finished drug in a single dosage form which belongs to the type of Narcotics Group II." The Metadona Maintenance Therapy Program, hereinafter abbreviated as PTRM "is" a series of therapeutic activities using Metadona accompanied by psychosocial interventions for opioid dependence patients according to the diagnostic criteria of the Third Classification and Diagnostic Guidelines for Mental Disorders " (Kementerian Kesehatan RI, 2013).

Users of opioid drugs will suffer from hypo salivation, leading to Dry Mouth (xerostomia). Swollen salivary glands, causing chronic sialadenitis as part of the autoimmune process, increases in bacterial sialadenitis which can get worse if bacteria gather in the duct due to disrupted salivation. Patients with chronic hyposalivation have many complaints including lack of lubrication and impaired function so that xerostomia appears and develops into caries (Kasuma, 2015).

\section{Method}

This research used descriptive analytic method with cross sectional design. The sample in this study amounted to 64 people consisting of 32 PTRM groups and 32 control groups who met the inclusion criteria. Samples were taken using a total sampling technique, which was taken according to the existing population.

The tools and materials used during the study were diagnostic sets, handscoens and masks, mouthwash, saliva collection cups and labels, tissues, cameras, litmus paper/ $\mathrm{pH}$ strips, washing soap and alcohol.

Patients who met the criteria were then explained about the research to be carried out, asked the respondent's identity, and asked the respondent's willingness to give consent form.

Saliva examination was carried out between 09.00 until 11.00 PM. Previously, subjects were given instructions that they were not allowed to eat or drink, and were not allowed to brush their teeth for a maximum of the last 30 minutes before the saliva examination began or a 30-minute pause if the subject had eaten or brushed their teeth. Respondents were instructed in a state of rest, looking down, closing their mouths, and not moving the tongue.

Saliva collection at this stage used the spitting method. After saliva had accumulated in the mouth, the subject then spit out the saliva into a cup until the saliva reached $10 \mathrm{ml}$. The saliva that had been collected was then put together and labelled. The saliva collected was then tested using lakmus paper.

Researchers then examined the respondent's teeth to obtain DMF-T index data. After the data were obtained, data processing and data analysis were performed according to the method used. Normality test was tested with saphiro wilk homogeneity. If the data were normally distributed, then the test used was Pearson Product Moment. If the data were not normally distributed, the test used was the Spearman Rank. If the P value was below 0.05, there was a relationship between salivary $\mathrm{pH}$ and the DMF-T index.

\section{Results and Discussion}

a. Univariate

Age of each samples is described Tabel 1.

Table 1. Distribution respondent based on age

\begin{tabular}{ccc}
\hline Age (year) & $\mathbf{n}$ & $\mathbf{f}$ \\
\hline $21-30$ & 6 & 18.8 \\
$31-40$ & 16 & 50.0 \\
$41-50$ & 10 & 31.2 \\
Total & 32 & 100.0 \\
\hline
\end{tabular}


Table 1 shows that respondents at the age of 31-40 were half of all respondents which were 16 people $(50 \%)$ and the lowest number was at the group of age of 21-30 which were 6 people $(18.8 \%)$. The youngest respondent was 21 years old.

Below is the description of $\mathrm{pH}$ saliva of all respondents.

Table 2. Distribution frequency of $\mathrm{pH}$ saliva of PTRM group

\begin{tabular}{ccc}
\hline pH saliva & n & f \\
\hline 5.2 & 1 & 3.1 \\
5.4 & 6 & 18.8 \\
5.6 & 6 & 18.8 \\
5.8 & 6 & 18.8 \\
6.0 & 3 & 9.4 \\
6.2 & 1 & 3.1 \\
6.4 & 4 & 12.5 \\
6.6 & 2 & 6.2 \\
6.8 & 2 & 6.2 \\
7.0 & 1 & 3.1 \\
Total & 32 & 100.0 \\
\hline
\end{tabular}

In table 2 the smallest salivary $\mathrm{pH}$ was 5.2 by 1 person $(3.1 \%)$. The most $\mathrm{pH}$ was owned by respondents $5.4 ; 5,6$; 5.8 each as many as 6 people $(18.8 \%)$. The largest $\mathrm{pH}$ was 7.0 , by 1 person $(3.1 \%)$.

Condition of caries prevalence of each sample is described in table 3.

Table 3. Distribution frequency of DMF $\mathrm{T}$ of PTRM Group

\begin{tabular}{ccc}
\hline Skor DMFT & n & f \\
\hline 3 & 3 & 9.4 \\
4 & 3 & 9.4 \\
5 & 5 & 15.6 \\
6 & 5 & 15.6 \\
7 & 5 & 15.6 \\
8 & 3 & 9.4 \\
9 & 3 & 9.4 \\
14 & 1 & 3.1 \\
17 & 1 & 3.1 \\
21 & 1 & 3.1 \\
28 & 2 & 6.2 \\
Total & 32 & 100.0 \\
\hline
\end{tabular}

In table 3 the DMF-T scores of 28 elements which were the highest scores in this examination were 2 people $(6.2 \%)$ of the total number of respondents and the smallest DMF-T score was 3 elements with the number of respondents as many as 3 people $(9.4 \%)$

\section{b. Bivariate Analyse}

Relation of $\mathrm{pH}$ and caries prevalence is needed to be described further.
Table 4. Association of $\mathrm{pH}$ saliva and DMF T

\begin{tabular}{clc}
\hline Test SPSS & \multicolumn{1}{c}{ Variable } & Sig \\
\hline Spearman's rho & $\begin{array}{l}\text { DMFT } \\
\text { pH Saliva TRM }\end{array}$ & 0,003 \\
$\begin{array}{c}\text { Correlation } \\
\text { Coefficient }\end{array}$ & & $-.501^{* *}$ \\
\hline
\end{tabular}

In table 4, after having been tested with Spearman's rho, it can be seen that $\mathrm{p}$ value was 0.003 . meaning that there was a significant relationship between salivary $\mathrm{pH}$ in the Methadone Maintenance Therapy group and the DMFT index.

Analysis of research data of the average DMF-T of PTRM group research respondents was 8.4 which was in the very high category. When compared to the control group, the average result of DMF-T was 2.1, which belonged to the low category. The results of the study in the control group mean salivary $\mathrm{pH}$ was 6.6 in the neutral criteria. Whereas in the PTRM group, it was found the average salivary $\mathrm{pH}$ was 5.8 in the acid criteria. All PTRM group respondents had caries problems. Based on the results of the examination of respondents in the Methadone Maintenance Therapy group, the DMF-T score was very high above 6.6.

The prevalence of caries in the control group was lower compared to that of the Methadone Maintenance Therapy group. Likewise, the mean saliva $\mathrm{pH}$ in the control group was neutral compared to the saliva $\mathrm{pH}$ of the Methadone Maintenance Therapy group with acid average.

The results showed poor health of the oral cavity in the Methadone Maintenance Therapy Program group, as a former drug addict (heroin). High dental caries in heroin users are caused by reduced production of saliva or saliva by the submandibular and sublingual glands causing dry mouth. Relationship of saliva with caries can be explained that saliva is needed to clean the teeth in sufficient quantities and to prevent the emergence of plaque that is high enough and that will make the atmosphere in the mouth become acidic, which causes caries.

Reduced saliva production which causes $\mathrm{pH}$ to become acidic and high dental caries in users of the Methadone Maintenance Therapy Program, in addition to the effects of these drugs is also caused by not meeting personal needs such as brushing teeth and eating foods that are low in sugar. Most of the drug users ignore the cleanliness of their teeth and mouth 
and the fulfillment of fibrous and watery foods such as vegetables and fruit.

Behavior of intending to consume heroin becomes an addiction while becoming an addict results in poor dental and oral health conditions. As addicts use the Methadone Maintenance Therapy Program, the fulfillment of personal needs such as maintaining oral health as well as the need for fulfilling healthy foods begins to be considered.

The results of the PTRM group show low salivary $\mathrm{pH}$ which means that the acid and DMFT index scores were very high. This shows conformity with the theory of Tarigan (2013) which states that this low salivary $\mathrm{pH}$ makes the inorganic elements of the enamel in the inner layer break down, so caries will occur.

This is in line with the theory of the occurrence of dental caries which states that saliva or acid saliva is one of the causes or factors that influence the occurrence of caries. In line with the results of Enrique's study, it is concluded that the DMF index using methadone therapy is higher than the control group (Enrique, Inés, Marcelo, \& Sylvia, 2015). Result of Riset Kesehatan Dasar (Riskesdas) 2013 shows that the average DMFT is 4.6. DMF-T research result is higher than DMF-T results of Riskesdas 2013 in Indonesia, if reviewed based on WHO criteria, the average value of DMF-T results from Riskesdas is considered high.

In line with the results of research from Protrka, according to the results of the study, the stimulated and unstimulated saliva flow were lower in the test group, and the $\mathrm{pH}$ of saliva was more acidic. The prevalence of caries was much higher in the test group than that in the control group, which might be associated with reduced salivary secretion and decreased saliva $\mathrm{pH}$ (Protrka, Katunarić, Filipović, \& Verzak, 2013).

Other research reported that patients who addicted to drugs had bad oral hygiene, xerostomia and high prevalence of dental caries and periodontal disease (Saini, Prabhat, \& Gupta, 2013). In opiate drug users, tooth loss, tooth extraction, and complete tooth decay especially on smooth surfaces and cervix are common. In addition, salivary hypo function among these patients causes xerostomia, burning mouth, difficulty eating, mucosal infections, and periodontal disease. Periodontal disease usually appears in the form of periodontitis, although there are also reports of gingivitis. Heroin users show poor oral health in terms of caries and periodontal disease. A study of heroin injections reports that regardless of their oral hygiene, these patients suffer from progressive dental caries (Shekarchizadeh, Khami, Mohebbi, Ekhtiari, \& Virtanen, 2013).

\section{Conclusion and Suggestion}

Mean of DMF-T and $\mathrm{pH}$ saliva of group Methadone Therapy Housing in Jogjakarta and control group are 8.4; 5.8 (acid) and 2.2; 6.6 (neutral). There is a relationship of $\mathrm{pH}$ saliva and DMF-T of group Methadone Therapy Housing. Further research is needed to know how to handle acid condition of $\mathrm{pH}$ saliva methadone user who had therapy.

\section{Acknowledgements}

I thank to respondents who are willing to participate in this research and the Housing of Methadone Maintenance at Jogjakarta.

\section{Reference}

Enrique, R., Inés, S., Marcelo, K., \& Sylvia, P. (2015). Dental and periodontal condition of a population in treatment for drug use. Pilot study. XVII, 34-39.

Isadora Gracia1, Rensa2, Minawati3, Teguh Sarry Hartono4, S. (2014). Dental Caries And Periodontal Disease In Heroin Addicts Who Receives Methadone Maintenance Treatmen. Damianus Journal of Medicine, 13(3), 191-198. Retrieved from file:// C:/Users/asus/AppData/Local/T emp/381-645-1-SM-1.pdf

Kasuma, N. (2015). Fisiologi dan Patologi Saliva. Andalas University Press, p. 54.

Kementerian Kesehatan RI. (2013). Pedoman Penyelenggaraan Program Terapi Rumatan Metadona.

Kementerian Kesehatan RI Badan Penelitian dan Pengembangan. (2018). Hasil Utama Riset Kesehatan Dasar. Kementrian Kesehatan Republik Indonesia, 1-100. https://doi.org/1 Desember 2013

Protrka, N., Katunarić, M., Filipović, I., \& Verzak, Z. (2013). Caries prevalence in heroin addicts. Acta Clinica Croatica, 52(4), 436-443.

Ramadhan, A., \& dkk. (2016). Hubungan Tingkat Pengetahuan Kesehatan Gigi dan Mulut Terhadap Angka Karies Gigi di SMPN 1 Marabaha. Kedokteran Gigi.

Saini, G., Prabhat, K., \& Gupta, N. (2013). Drug addiction and periodontal diseases. Journal 
Jurnal Riset Kesehatan, 9 (1), 2020, 32 - 32

DOI: $10.31983 /$ jrk.v9i1.5641

of Indian Society of Periodontology, 17(5), 587. https:/ / doi.org/10.4103/0972-124X.119277

Shekarchizadeh, H., Khami, M. R., Mohebbi, S.

Z., Ekhtiari, H., \& Virtanen, J. I. (2013).

Oral Health of Drug Abusers: A Review of
Health Effects and Care. Iranian J Publ Health, 42(9), 929-940.

Tarigan, R. (2013). Karies Gigi. Ed 2. Jakarta: EGC 